\title{
Article
}

\section{Beyond the hegemonic narrative - a study of managers}

\author{
Vickers, David \\ Available at http://clok.uclan.ac.uk/5216/ \\ Vickers, David ORCID: 0000-0002-7220-8789 (2008) Beyond the hegemonic \\ narrative - a study of managers. Journal of Organizational Change \\ Management, 21 (5). pp. 560-573. ISSN 0953-4814
}

It is advisable to refer to the publisher's version if you intend to cite from the work. http://dx.doi.org/10.1108/09534810810903216

For more information about UCLan's research in this area go to http://www.uclan.ac.uk/researchgroups/ and search for < name of research Group>.

For information about Research generally at UCLan please go to http://www.uclan.ac.uk/research/

All outputs in CLoK are protected by Intellectual Property Rights law, including Copyright law. Copyright, IPR and Moral Rights for the works on this site are retained by the individual authors and/or other copyright owners. Terms and conditions for use of this material are defined in the policies page.

\section{CLoK}

Central Lancashire online Knowledge www.clok.uclan.ac.uk

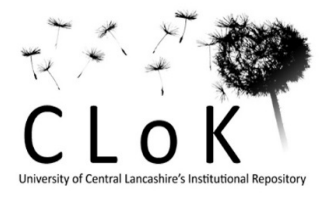


Beyond the Hegemonic Narrative - A Study of Managers.

David Vickers

Lancashire Business School, University of Central Lancashire, Preston, UK. 


\begin{abstract}
:
Purpose - The aim of this paper is to investigate managerial behaviour through the use of narrative analysis to identify stories that are often ignored, silenced or 'missed out' by the hegemonic managerialist narrative.
\end{abstract}

Design/methodology/approach - The data was generated from an eighteen month period of participant observation of a group of managers after they were acquired as part of a $\$ 1$ billion takeover. The analysis considers the strategic perspective, the managerial perspective and the 'small' story.

\title{
Findings
}

Strategy can be diverted or altered by managers lower down the organization. This is consistent with Dalton (1959) where managers lower down the organization adapt and change strategy to make it work. The need for greater consideration of the value of managers acquired as part of a merger or acquisition.

\section{Research limitations/implications}

Participant observation and ethnomethodological narrative analysis have the potential to go beyond the hegemonic managerialist literature and identify a much more complex picture. However, such research is always open to criticism as being from the author's 'own perspective' and appearing to claim 'omnipresence'. Other stories have been given voice but it is never possible to say that all stories have been recovered from the silencing processes of the organization.

\section{Practical implications}

A clearer understanding of how management operates within an organization in practice. This enables organizations to reconsider how they engage managers. In addition the paper highlights the need for more focus on acquired people and processes post acquisition. 


\section{Originality/value}

This paper aims to provide an insight into management behaviour beyond the usual treatment of managers as an amorphous mass as is common in most of the hegemonic managerialist narrative.

\section{Key Words:}

narrative analysis, managers, strategy, merger, acquisition 


\section{Introduction}

Managerialism is perpetuated by the hegemonic narrative that dominates the literature and teaching in our business schools. There is an assumption that managers are an amorphous mass that have one view - the 'right' view. The argument favours planned strategy and focuses on 'progress' and maximizing efficiency. Anyone who does not agree with this view is 'resistant to change' or lacking 'commitment' and needs to be brought into line or silenced. This ‘managerialism' also pervades the managerial behaviour and literature in relation to mergers and acquisitions. This paper represents the managerial voices that choose to differ and tells the story of a group of managers who were able to divert and alter the strategic intent of the top managers to 'rationalize' a recently acquired business. The paper is based on a period of eighteen months of overt participant observation where the author was an established manager in the organization with wide ranging access. An American multinational (Chemco) acquired part of a UK multinational (HCI) for around \$1 billion. The paper uses narrative analysis to go beyond the usual 'strategic' or 'managerial' readings of such events and uncovers the 'small stories' of managers. The paper is not about 'resistance' or ‘emancipation’ - lets not forget we are still telling stories of managers here!

\section{Managerialism}

Managerialism is generally seen as the pursuit of organizational efficiency at all costs (Thompson and McHugh, 1995: 12). Managerialism is all pervasive in the private sector and now the public sector (Bach et al, 2005; Harris, 2005). It is deeply embedded in the teaching of new managers in our University system and is the dominant discourse in our literature.

Chandler's (1962) brand of strategy with a unitary management focus on planning and profit maximization is a key building block for managerialism. Many MBA students are able for 
example, to chant the mantra 'structure follows strategy'. The managerialist perspective is also represented in the change literature with the bastardization of Lewin's (1943) holistic approach to change into the three words of 'unfreezing - change - refreezing'. There are a plethora of models which suggest that a planned pseudo-scientific approach to change is possible (e.g. Beckhard and Harris, 1977; Kotter and Cohen, 2002). There is an assumption that there is one voice that is representative of management and that it is 'right'. Anyone who does not agree with this view is seen to be 'resistant' to change (Kotter and Schlesinger, 1979). Managerialist narrative also makes claims to be the champion of 'progress' (Washbourne and Dicke, 2001). Organizations are seen to be objective, scientific, in pursuit of efficiency and waste reduction and free from subjectivity and personal managerial whims. This leads to theory which is universally applicable and holds 'true'.

The author is not arguing here about the right of managers to pursue efficiency but the presumption that effectiveness and efficiency are synonymous with management alone. The hegemonic narrative assumes that management has a monopoly on these very common organizational goals. Parker (2002: 10) has described ‘managerialism’ as a “generalized ideology of management” which appears to support and attempts to legitimize management holding a monopoly on logic, rationality and the techniques of effectiveness and efficiency. In addition the author would also like to point out the obvious fact that the very idea of 'managerialism' is a generalization which makes the assumption of a unitary management group seeking to act upon the other stakeholders (e.g. employees, customers, suppliers, investors). This assumption is fortified by the general anecdotal perception that such a unified group does exist in this or that organization and possibly in society at large. However, the question of the existence of such a unified and amorphous group is open to empirical study. There are several studies which suggest that managers are heavily engaged with each other in 
politics and resource allocation power struggles (Stewart, 1967; Stewart, 1976; Stewart, 1982; Kotter, 1982; Pettigrew, 1985). There are also studies which suggest that senior managers tend to develop strategy as an ongoing dynamic process (Mintzberg, 1973); have to ask their subordinates to find out what is actually going on (Mintzberg, 1973); 'muddle through' (Lindblom, 1959); make decisions limited to what they know (March and Simon, 1958) or 'post hoc rationalize’ events in their own favour (Mintzberg, 1978).

Particular ethnographic studies of managers appear to demonstrate that management does not always operate as a cohesive or amorphous group within an organization (e.g. Dalton, 1959; Watson, 1994). Rather management groups are fractured along functional, professional, hierarchical, geographical and cultural lines amongst others.

Dalton (1959) for example, argued that managers lower down the organization adapted strategy from senior managers to make it work in practice. Middle managers did so in a covert series of alliances in order to stave off reprisals from above. This is consistent with a more 'processual' (Whittington, 2000) approach to strategy as suggested by the likes of Mintzberg (1978) and Cyert and March (1963). Dalton’s work also clearly demonstrates the politicking that managers engage in rather than treating 'management' as one body with the sole intention of profit maximization or efficiency.

\section{Mergers and Acquisitions}

In the mergers and acquisitions literature this managerialist perspective also tends to dominate. Haspeslagh and Jemison (1991) identified what they call the 'strategic school' and the 'capital market school'. The strategic school tends to argue that mergers can be planned or predicted and looks for criteria by which to predict successful mergers and therefore to take the 'right' strategic actions. For example Lubatkin (1983) argues that the key characteristics 
of successful mergers are absolute size, relative size and relatedness. There may be a desire for synergies where businesses are similar or complimentary whose combined worth is greater than the two separate worths of the individual businesses. The benefits of this approach are supported by several authors (Barney, 1988; Harrison et al, 1991; Bengtsson, 1992; Collis and Montgomery, 1998). The capital market school on the other hand concentrates on the creation of economic and financial value of mergers and acquisitions rather than looking at what makes for a successful merger. This approach also tends to ignore managerial motives. A typical example of this research is Willmott and Wigdahl's (1997) assessment of mergers in the European Chemical Industry. They argue that most mergers and acquisitions appear to be in the higher added value businesses. They also argue that though many mergers and acquisitions are doomed to failure (60\%) when they get it 'right' they outperform peers in the stock market. The economic argument suggests that an acquirer is able to extract more value from the target business because of more efficient management (e.g. Fama, 1980; Varaiya, 1987).

These two perspectives remain the two dominant drivers in the literature and the media for the analysis of mergers and acquisitions. However, there is research which counters theses views. Many mergers and acquisitions do not deliver on the promises made by acquirers (e.g. Kitching 1967, Louis 1982) and therefore many of the managerialist claims are debatable. Some mergers and acquisitions are driven by the motives of senior executives who overestimate their own abilities in managing target entities more profitably (e.g. Gupta et al, 1997; Hayward and Hambrick, 1997). Other mergers and acquisitions are motivated by the impact they will have upon the compensation of senior managers through the initial positive effects on share price followed by negative impacts in the medium term (e.g. Baker et al, 1988; Tosi and Gomez-Mejia, 1989; Wright et al, 2002a; Wright et al, 2002b). 
The dominant literature tends to focus on merging businesses or top management rather than employees lower down the organization (Shirley, 1977). Haspeslagh and Jemison (1987:56) suggest that mergers and acquisitions normally result in resource rationalization or the disposal of assets which in turn destroys non-economic value. A manager may find their power, status, and career prospects dashed by the 'economic' rationalization of business units. The macro picture assumes that people are mobile and business units will co-operate with each other. There is an irony here in that the people who are asked to destroy non economic value are those who built it up over many years. In addition cultural clashes tend to be glossed over in this macro view. Yet research suggests that cultural clashes reduce the shareholder value (Chatterjee et al, 1992); cause deterioration in operating performance (Very et al, 1997) and there is a tendency for new owners/managers to be more bureaucratic (Levison, 1970). Before moving on to consider the story of Burnsland the paper will now discuss narrative analysis and the methodology.

\section{Narrative Analysis}

Quite simply put narrative analysis is about the use of stories as a primary way of making sense of an experience (Mishler, 1986). Chamberlain et al (1997) argue that these stories are a product of an individual's organization of non-systematic encounters to help in the creation of meaning from experience. Denzin (1989: 37) suggests that "a narrative is a story that tells a sequence of events that are significant for the narrator and [the] audience. A narrative has a plot, a beginning, a middle and an end. It has an internal logic that makes sense to the narrator. A narrative relates events in a temporal, causal sequence of events that have happened”. Denzin’s view is echoed by Ochs and Capps (2001: 57) who argue that the narrative is also likely to come from a particular perspective. Labov (1972: 359) similarly 
calls narrative analysis a "recapitulation of past experience” and Ricoeur (1984: 52) talks of the "the temporal character of human experience." The exciting aspect of narrative analysis is perhaps best summed up by Franzosi (1998) who argues that "narrative texts are packed with sociological information, and a great deal of our empirical evidence is in narrative form.” However, the author argues that the term 'text' is misleading. Some narrative analysis is indeed conducted from texts but the narrative can be verbal in line with the great histories of saga, folk lore, story telling and myth.

Barry et al (2006) argue that narrative analysis is 'endotextual', 'exotextual', or a combination of the two. Endotextual analysis tends to privilege the text and uses techniques from literary theory. It works within the text and may explore its relationship to other texts. The endotextual and literary approach to narrative tends to be followed by the likes of Labov (1972), Polkinghorne (1988) and more recently Boudens (2005a). Exotextual analysis privileges the context by placing the text in its context. This form of analysis usually involves an ethnographic production or a socio-political reading. Boje (1991) uses and exotextual approach which focuses as much on what is left out as much as what is told. Where endotextual and exotextual analysis are used together there tends to be a move from one to the other and earlier readings are embedded into later ones rather than both processes of analysis being used in tandem.

This paper follows an exotextual approach and is particularly concerned with the idea of ‘narrative as a social process’ and ‘narrative as political praxis’ (Langellier, 1989). Narrative as a social process is primarily an ethnomethodological perspective. Narrative as political praxis is concerned with the unequal distribution of rights to storytelling. Who can 
speak, who cannot and which stories are allowed to form the grand narrative or dominant discourse in the organization.

Narrative as a social process provides a way for the researcher to identify the meaning individuals ascribe to their lives and at the same time to construct a social 'reality' (Garfinkel, 1967). Goffman (1983) takes Garfinkel’s approach and applies it to social organizations. Narrative shapes the organizational identity and in turn the organization is shaped by and shapes other organizations by social interaction. Boje (1995: 1000) suggests, organizations are "a multiplicity, a plurality of stories and story interpretations in struggle with one another”. Rather than searching for one story to narrate events, we are engaged in a search for meanings. Thus, “...the truth of the story lies not in its accuracy but its meaning” (Gabriel, 2000: 135).

Narrative as political praxis is about power relations and how a dominant discourse comes to be and maintains itself. Barton (2007) in her study of disability support groups shows how dominant narratives are told without interruption or truncation and sometimes collaborated by powerful figures. Whereas narrative associated with failure, negativity or challenge is not received as a legitimate contribution, is often interrupted or truncated and powerful figures may reformulate stories and identities to fit the dominant narrative. These non-dominant or 'silenced' narratives are described by Georgakopoulou (2006: 238) as ‘non-canonical narratives’. Georgakopoulou (2006: 239) argues that narrative analysis can involve "legitimating 'neglected' stories" and enables the testing of the hegemonic narrative of the organization. This is achieved by considering the "hidden, small, unofficial and fragmented practices either in the fringes of official sites or in unofficial sites away from carefully chosen cultural niches” (Georgakopoulou 2006: 254). This idea of non-canonical 
narrative stems from communities of practice theory where Brown and Duguid (1991) coined the term 'non-canonical communities' to describe communities that operate outside the main stream or dominant narrative. Peters and Waterman (1982) described these groups a 'skunk works' and the work of Orr (1996) in his study of Xerox technicians shows how such communities operate in practice within and in spite of the main stream culture. The mainstream narrative tends to "gloss over differences in other accounts" (Boje, 1995: 1115). Thus the narrative approach is able to get behind the hegemonic narrative by exploring other versions of events. These versions have either been missed out of the macro account or silenced.

Ethnomethodological Narrative Research is perhaps best summed up by Boje’s (1995: 997) account of Tamara, a long running play in Los Angeles. In Tamara, the audience individually chooses, by moving around, which of twelve story-telling characters to follow across twelve stages. This gives the possibility of $479,001,600$ viewings of the same story. As Boje argues, two characters in a scene can have a conversation and each walk away with a different interpretation. Similarly, each audience member has the possibility of a different interpretation of the same story.

Boje (2002) provides a comprehensive review of different methods of narration for use in organization studies. Three of these approaches are explored here - 'hegemony of narrative', 'grand narratives', and 'microstoria'.

First, hegemony of narrative is where there is a 'dominant paradigm' which creates a grand narrative to interpret events. This tends to be monological and denies the idea of multivocality (multiple voices). This idea of hegemony of narrative is supported by Gabriel 
(2004b: 24) who argues that organizations employ considerable resources that "stand in the way of narratives and include rule books and manuals, recipe books and reports, instructions and orders conveyed by word of mouth, paper and electronic means, circulars and so forth”. This view is clearly demonstrated by Boje et al (2005b) in their study of McDonald's. The monological, grand narrative of McDonald's suggests a planned strategy, a 'scientific' approach to work organization and slight variations in menus and recruitment to fit strategy to culture.

Second, the idea of the grand narrative approach "is to shatter the grand narrative and to problematize any linear mono-voiced grand narrative of the past by replacing it with an open polysemous (many meanings) and multivocal (many-voiced) web of little stories” (Boje, 2002:12). This enables other stories to be resituated within the grand narrative. Along similar lines to Boje’s grand narrative approach, Gabriel (2004a: 3-4) argues that there are “a wide range of stories existing outside the managed terrains of organization”. Such a plurivocal approach is demonstrated by Boje’s (1995) study of Disney where a wider or grander narrative shows how people are taken off the credits of films and their files are removed from the organizational memory when they leave after differences of opinion with Walt Disney.

Finally, the microstoria approach prefers local knowledge and little people’s histories and ignores the popular heroic great man accounts (e.g. Watson, 2000, Packard, 2006) of much of organization studies. Bamberg (2004) has suggested the term 'small stories' for such an approach. This includes micro stories and these "counter-stories fashion a web of stories, an antenarrative soup out of which the tension between microstory and macrostory lives” (Boje, 2002: 61). This is similar to the view expressed by Czarniawska (1998: 49) who argues, "by showing how macropictures are drawn, micro studies problematize the taken for 
granted”. This paper recounts three stories - the strategic view, the senior management view, and the small story view.

\section{Methodology}

This paper draws on an eighteen month period of participant observation where the author was employed as a Human Resource Manager at a manufacturing site 'Burnsland’ (Vickers, 2005). As Jessop and Penny (1999: 213-6) argue we are always offering a view from 'somewhere' and whilst this may not be an “all-seeing eye, a view from everywhere” equally we cannot provide a view from 'nowhere'. As narrators therefore we need to take care to justify our analysis and clearly identify our research position in our writing. In the case of this paper the author makes no claims to omnipresence. However, as a senior manager responsible for human resource issues a story of redundancies and restructuring provide the participant (observer) with wide ranging access to group and one to one meetings.

The author does not aim to 'privilege his own point of view' (Boje et al 1999: 357) but has attempted to "step back argue and be self-reflexive about the ways in which he... recontextualize[s] their meanings”. The author attempted to do this by a combination of reflexive questioning of himself and by testing the final narrative with other colleagues involved at the time. This is in common with the view expressed by Gabriel (2004b: 29) that it is not merely a 'celebration' of the narrative designed to 'seduce and deceive' but is more about exploring deeper meanings from personal experiences.

There are a number of dangers with the narrative approach as Gabriel (2000: 151) suggests. Most likely are the selective use of narratives to promote preconceived ideas or agendas and 
seeing stories as facts and insisting second hand observations can be viewed objectively. Whilst the author's observations are largely first hand, he does not see the events as objective but as a series of social constructions.

Whilst the author had spent ten years working at HCI it had been at other locations. This meant that the author had a strong understanding of HCI culture and jargon but was a newcomer to the practices at Burnsland and arguably more consciously aware of these. In addition the author was able to experience the feeling of being acquired by Chemco. All other HCI staff transferred automatically under transfer of undertakings legislation. However, the author was able to choose whether to transfer and after positive conversations with managers in Chemco and HCI the author chose to transfer. Throughout the eighteen month period of participant observation the author took notes on a daily basis. The culture of managers using note books normally enabled the author to take notes in situ. All the narrative analysis in this paper is taken directly from these notes rather than a blurred recollection of events or some form of 'post-hoc rationalization' (Mintzberg, 1978). The author will now recount three stories that tell the events of HCI, Chemco and Burnsland.

\section{A 'Strategic’ Overview}

The global chemical industry tends to operate as an oligopoly. The major multi national players in the chemical industry made the 'strategic choice' to realign their business portfolios to create more synergistic chains. For example Chemco’s acquisition of HCI's businesses; HCI's move away from the peaks and troughs of the 'ten year' cycle in the heavy chemicals sector; and 'Unichem's' sale of 'specialities' businesses to HCI because they too were seen as cyclical. These events triggered further events throughout the chemical sector. 
In the particular product market the author is concerned with here, the Chemco argument was for an integrated production chain with access to the three key world markets of the Americas, Europe and the Far East. The acquisition of HCI's business unit moved Chemco from second place to first place in terms of market share. This sparked off other acquisitions by the now dethroned previous market leader from Japan of other smaller European players. It also provoked the aggressive act of building production plants in America by the third place player in the market, from South Korea. Chemco’s business unit Directors persuaded the Chemco Main Board that the purchase of HCI's interests was a good thing. At about this time sales had peaked and the market was starting to become saturated with over production. The Chemco argument had been to buy HCI's interests at the height of a growth market in order to increase market share, synergy, profitability, and new product development. This sits comfortably with the strategic school literature on acquisitions (Lubatkin, 1983; Barney, 1988; Harrison et al, 1991; Bengtsson, 1992; Collis and Montgomery, 1998). However, shortly after the purchase of HCI's assets there was a major down turn in the market which was made worse by a rapid and unpredicted crash in Far Eastern economies. Many producers in the Far East started to ‘dump’ surplus product on the market at cost price, or in some cases at a loss.

HCI had offered several of their businesses for sale to other major players in the chemical industry; this was well known to employees within HCI from various internal communications. There was a need to sell after a major acquisition of 'specialty' businesses from Unichem, which put HCI into several billion pounds of debt. HCI’s business unit at Burnsland, which was part of a larger Division, was not regarded as one of the businesses for sale. Chemco and another Petrochemicals company made rival offers to buy the Division from HCI. Ultimately, HCI agreed to sell to Chemco. Chemco had indicated that it was 
keener to buy the business unit and to ensure that the rest of the Division, with its heavy investment costs was also acquired, HCI insisted on a subtle twist in the deal. HCI wrote into the deal that the business unit must be transferred at least a month after the rest of the Division. In addition HCI mindful of previous history between HCI and Chemco wrote an additional clause into the transfer contract. Several years earlier Chemco had bought another HCI business in the UK and within a year had announced closure of the business with the intention to make over 400 redundancies. Eventually, this closure did not take place due to a number of issues, not least of which was the blocking of another takeover deal by the European Commission. However, by signalling the intention to make these redundancies Chemco had caused severe embarrassment to HCI as it shared a site with Chemco and was accused of having prior knowledge of Chemco’s intentions. Therefore HCI wrote into the deal that Chemco was not allowed to change the terms and conditions of employees it acquired for at least four years. This in itself did not prevent redundancies however; the lucrative redundancy payments scheme was written into the employment contract and thus made redundancies potentially very expensive for Chemco.

\section{'Management' View}

At the business unit level is a second story - the 'Management' view. Again this story fits with some of the dominant narrative of acquisitions theory most notably the capital market school (e.g. Fama, 1980; Varaiya, 1987). There is evidence at this business unit level that within Chemco this acquisition was driven by Directors within the Chemco business unit. The arguments may well have been presented as strategic and financial to the Main Board of Chemco but managerial desire to create a larger business can be seen as the key driver. The Senior Managers of the Chemco business unit were keen to point out the possibilities that an 
integrated product chain afforded them in a worldwide market. After merger the same managers referred to an historic meeting, where they had written on a flip chart ways in which they could improve their business to meet the Chemco profitability targets. The one key thing they desired above all was to find some form of alliance arrangement with HCI in this market, as this would give greater scope in Europe and America. However, behind these drivers were career aspirations for the most senior business unit manager to achieve a place on the Board of Directors of Chemco, and promotions for his two key managers to run two large global business units. On day one of the takeover of HCI's assets these two managers were appointed to Chair the two new businesses units within the Division. However, within a year the most senior manager, who had been the architect responsible for persuading the Main Board, left the organization under acrimonious circumstances. This coincided with a major down turn in the global product market along with heavy financial losses in Europe and a failure to achieve expectations for the business. At this point Chemco also announced its intentions to invest in pharmaceuticals and agrochemicals and to look for other ways to run and finance its other businesses (of which this was one) through joint ventures etc. Thus realignment of the Chemco portfolio was decided twelve months after actions by other players in the global Chemicals sector (e.g. HCI and Unichem).

\section{Small Stories and 'Good Foot Soldiers'}

The final story is from the micro level. The former HCI managers at Burnsland were initially very excited by the possibilities that the acquisition afforded them. They talked about the combining of different technologies in a longer chain from development to production, plus the chance to share creative possibilities and former process secrets. Indeed the author himself chose to join Chemco from HCI on the strength of this feeling and evidence. There was little resistance to the acquisition locally as Burnsland had specialist capacities not really available 
elsewhere in Europe and had more mass production potential than any other manufacturing facility in the world. Yet most of the author's story here is about how this acquisition turns into a story of 'resistance' and failing to deliver stated strategic objectives on time.

Some years earlier HCI was subjected to a take-over bid which prompted management to pursue many defensive strategies. This included the provision of a contractual twelve month notice period to the managers and professionals as an expensive, disincentive to potentially hostile take-over merchants. Burnsland had a long HCI history and was the largest employer in the local community in Scotland. A new site manager arrived from America, an old Chemco employee with thirty years experience.

Chemco already owned a similar business unit on the European continent, producing symbiotic products. In addition Chemco also acquired another business unit from HCI based in mainland Europe. In view of this, Chemco senior management in the US decided that they could make better profits by rationalizing production lines. After protracted debate the Chemco senior managers decided to accept the projected output figures of the site in Holland against the actual output figures of Burnsland in the UK. One of the senior production managers at Burnsland argued publicly and vehemently that this was the wrong decision. However the Directors still decided to close three out of the nine production lines at Burnsland. The new Site Manager told the Senior Production Manager that he would be moving on to another job, yet to be defined. This was done in front of all the other senior managers at Burnsland and caused anger across the management team as it was seen as punishment for him having argued against the view of more senior management. 
The Site Manager then asked the Operations Manager and the HR manager to make a series of redundancies within a tight timetable, thus saving money, and to prepare the lines for closure.

The Operations manager and HR manager, called a meeting of all the middle managers, representing every department in the unit and agreed they would hold weekly meetings to progress the redundancies as swiftly as possible. This meeting became known as 'the engine room', the place where the process of retrenchment was to be managed. The title was taken from a previously successful redundancy exercise that had been conducted at Burnsland several years earlier by HCI.

However, neither the Operations Manager nor the HR Manager had any intention of closing the production lines in line with Chemco strategic timescales and nor did the middle managers. However, they were formally tasked with making redundancies as swiftly as possible and officially that was what the engine room meetings were for. The Site Manager had a standing invitation to participate in the meetings, but generally did not, until he began to worry that the promised redundancies were not happening fast enough.

The engine room examined the employment contracts of their management and professional staff and concluded that the twelve month notice period was a given. In addition the engine room also consulted a previous redundancy agreement and HCI custom and practice that had never made a compulsory redundancy in over twenty years. They then assured the Site Manager that in all honesty they would make the redundancies as swiftly as possible through a voluntary redundancy process in line with former HCI policies. At each meeting a list of potential names was considered and sometimes added to. They began to process a few cases, 
where it was known that employees did in fact wish to leave the company and they arranged redundancy packages for them. In this way they made a few voluntary redundancies as slowly as possible, while claiming they were working as fast as possible.

The Chemco way of redundancy, was dominated by American employment law. Chemco employees were issued with a notice letter, usually giving them three months notice, and they were immediately notified of being redundant. When the three months was complete, the employee left with redundancy pay, which was less generous than the HCI terms and conditions.

When the Site Manager attended the engine room meeting, the managers would present the figures as if great progress was being made. When the Site Manager was absent, the meeting examined all possible means of slowing the process down. Behind the scenes, the HR manager and the Operations Manager continually explained to the Site Manager the intricacies of UK employment law, HCI custom and practice and the need to consult with UK unions.

Although many people were made redundant, the delayed redundancy process allowed the production lines to stay open long enough for further problems to 'emerge', which meant that product transfers to the former HCI business unit in mainland Europe became the focus of the delay, rather than the process of redundancies at Burnsland. The three Burnsland production lines remained open for many months longer than the intended 'strategic' closure date and this delay enabled commercial managers to secure more product transfers to, and more investment in, Burnsland's remaining lines. The former HCI business unit in mainland Europe has subsequently been completely closed down as Burnsland has managed to demonstrate 
greater profitability and delivery. The managers at the business unit in mainland Europe had a history in HCI (which continued into Chemco) of making big and false promises on future output to gain additional scarce investment resources to the detriment of Burnsland.

At various stages the Site Manager was unconvinced that it was possible to achieve the redundancies by voluntary means. However, at each turn of the story the Operations Manager and the HR Manager were able to dissuade him from changing direction to a compulsory process. For example, on one occasion the Operations Manager reiterated that the redundancy target of about 160 people was already half met and the HR Manager added to the impression that the redundancies were on schedule by quoting a further nine employees were due to leave with the transfer of certain IT staff into a contractor service.

The Operations Manager and the HR Manager were also able to draw on their informal relationship with local trade union officials. There was one particular full-time union official based in an office close to the site. This union official was employed by the largest union represented at Burnsland. The Burnsland site constituted a large proportion of his union's membership. If the members were redundant, then he could be also. In addition the other unions at the site accepted his dominant membership position as giving him the lead in negotiations with the company.

The HR Manager had several discussions with the local full-time official in private and sometimes with the representatives of the other two unions, along with local union representatives from the work force. Without being explicit, he shared with the union the fact and likely extent of the redundancy program. He also indicated that the engine room managers intended to delay the final phase of redundancies for as long as possible in an 
attempt to gain more investment and hence, greater security for the remaining lines at Burnsland. The Unions were able to assist the Operations Manager and the HR Manager by using the grievance procedure to stall any thought of compulsory redundancies.

\section{Discussion}

The 'strategic overview' narrative would probably form a good start point for a case study for discussion of strategy with a group of MBA students. This narrative could be utilized to argue the case for strategic choice, planning and profit maximization. Whereas, the 'management view' narrative sits comfortably with the work of those who argue that mergers and acquisitions are driven by the power motives of senior managers (e.g. Gupta et al, 1997; Hayward and Hambrick, 1997).

However, the first story has the potential to be riddled with post hoc rationalizations of 'choices’ being made as well as ignoring the detail of events at a micro level. It may appear as though businesses in the chemical industry have made rational and logical choices in selling cyclical businesses or buying businesses that enable them to "stick to the knitting" (Peters and Waterman, 1984) of their core strategy. However, at best these 'choices' are cognitively limited to the chemicals sector - as such, ‘choices’ are blinkered. This would be consistent with Porac et al's (1989) study of the Scottish Knitwear industry where businesses appeared to be myopic and fail to recognise competition from elsewhere. At worst these 'choices' are really 'evolutionary' (Whittington, 2000) with one firm attempting to follow another firm whose strategy appears to be successful - rather than actually 'choosing'.

The second story assumes that 'management' is one amorphous grouping of people who all agree with a unitary agenda for the organization. This is consistent with Parker's (2002) view 
that the whole idea of 'management' is about being logical, rational and appearing to have a monopoly on being 'right'. The 'management view' story was widely known throughout Chemco and to some extent such stories take on mythical proportions. The story suggests the ability of senior management to choose and control events. It is also difficult to see how someone inside the organization could challenge such a positive aim for a collective future of success or 'progress' (Washbourne and Dicke, 2001). The hegemonic narrative would doubtless be fashioned from these first two stories.

However, the 'small story' generates a wider or grander narrative. This story does not begin with an assumption that top managers are 'right' and make choices that middle managers blindly and unquestioningly inflict on employees who either accept or 'resist'. Instead this story demonstrates how middle managers attempt to influence and redirect strategic intent. Rather than accepting the unitary 'choice’ model the small story of Burnsland demonstrates a more dynamic processual and political approach.

The small story from Burnsland clearly demonstrates how narrative analysis is able to give voice or voices to others who are normally excluded or silenced by the hegemonic narrative (Boje, 2002; Gabriel; 2004b). The small story identifies a plurality (Boje, 1995) of voices and how they are able to operate covertly in spite of the managerial pressures upon them. There is also an irony in that this plurality is lost in a process of unification against the hegemony.

The hegemonic view is that mergers and acquisitions are all about increasing profitability (Chandler, 1962) or economic value (e.g. Fama, 1980, Varaiya, 1987). However, this small story highlights the importance of power relations and politics post acquisition (Langellier, 1989). 
The power relations and political issues involving managers lower down the organization have been identified by a number of authors (Stewart, 1967; Stewart, 1976; Stewart, 1982; Kotter, 1982; Pettigrew, 1985). However, these voices are generally seen to be outside the mainstream hegemonic narrative of managerialism or are glossed over very quickly. Dalton's (1959) ethnographic approach found that coalitions of managers lower down the organization adapted and changed the strategy determined higher up the organization. This tended to be done in a covert way as middle managers were keen to avoid reprisals. When the author recounts Dalton's work and his own research to managers they can usually identify similar stories and behaviours in their own organizations. Yet these stories are themselves silenced or ignored by the vast majority of the hegemonic narrative of managerialism. This is perhaps partly down to the fact that managerialism is dominated by simple formulaic models that 'can be applied in all contexts'. However, this paper and Dalton (1959) disabuse us of the notions that; there is an amorphous unitary mass called 'management', senior managers are in 'control' of an organizations 'progress', and senior managers are 'right' and the rest of us 'resist' change. Whilst managers who hear these stories say that they ring true it is the managers themselves who perpetuate the plethora of managerialist publications by buying them in search of a simple step by step perfect solution when one will never exist.

By using an ethnomethodological narrative approach a grander narrative is uncovered rather than being ignored, silenced or missed by an hegemonic account. This has generated a clearer understanding of how management operates within an organization in practice. Rather than accepting the managerialist mantra of unitarism this paper calls for the reconsideration of how to engage managers lower down the organization. This is especially so in the case of managers who have been acquired. It is the acquired managers who have the knowledge of 
how to run the newly acquired business and as such, there needs to be a greater focus on acquired people and processes post acquisition.

\section{Conclusion}

This paper has used an ethnomethodological narrative analysis based on an eighteen month period of participant observation where the author was a manager. The author identifies a much more complex picture of managers in action than tends to be shown in the hegemonic managerialist literature. Whilst this participant observation process is open to criticism and omnipresence is not achievable, the paper does provide a deeper reading of management behaviour. Narrative analysis gives voice to more stories although it is never possible to say that all stories have been recovered from the silencing processes of the organization.

The key finding of the paper, which is consistent with Dalton (1959), is that strategy can be diverted or altered by managers lower down the organization. This runs counter to the hegemonic managerialist narrative which argues for a unitary approach driven by a planned strategy (Chandler, 1962) and a focus on efficiency. The small story narrative that is told here has explored managerial social processes and power relations issues that have also been noted by others (e.g. Stewart, 1967; Mintzberg, 1973; Stewart, 1976; Stewart, 1982; Kotter, 1982; Pettigrew, 1985). Much of this research is at the margins of the mainstream hegemonic narrative which seems more intent on producing simple models that are universally applicable.

In addition the paper suggests that organizations should reconsider how to engage managers lower down the organization. This is particularly the case in relation to mergers and acquisitions. Despite the acquiring senior managers being credited with having the skills to 
maximize market share, economic value and business returns (e.g. Fama, 1980, Lubatkin, 1983, Varaiya, 1987, Barney, 1988, Harrison, 1991) this paper argues against this position. The paper has shown how managers who have been acquired tend to have the knowledge of how to run the newly acquired business and can do so to the detriment of the strategic 'plan'. As such, the author would argue that where rationalization does not necessitate the complete closure of the acquired business unit there needs to be a greater focus on acquired people and processes post acquisition. 


\section{References}

Bach, S., Kessler, I. and White, G. (2005), “Employment Relations and Public Services “Modernisation” under Labour”, Personnel Review, Vol. 34 No. 6, pp.629-633.

Baker, G.P., Jensen, M.C. and Murphy, K.J. (1988), “Compensation and incentives: practice vs. theory”, Journal of Finance, Vol. 43, pp. 593-616.

Bamberg, M. (2004), “‘Small Stories’ Talk, Small Stories and Adolescent Identities”, Human Development, Vol. 47, pp. 331-353.

Barney, J. (1988), "Returns to bidding firms in mergers and acquisitions: reconsidering the relatedness hypothesis”, Strategic Management Journal, Summer Special Issue, Vol. 9, pp.7178.

Barry, D., Carroll, B. and Hanson, H. (2006), “To Text or Context? Endotextual, Exotextual, and Multi-textual Approaches to Narrative and Discursive Organizational Studies”. Organization Studies, Vol. 27 No. 8, pp. 1091-1110.

Barton, E. (2007), “Disability Narratives of the Law: Narratives and Counter-Narratives”, Narrative, Vol. 15, No. 1, pp. 95-112, January.

Beckhard, R. and Harris, R. T. (1977), Organizational Transitions: Managing Complex Change, Addison Wesley Publishing, Ontario. 
Bengtsson, A. M. (1992), Managing Mergers and Acquisitions: A European Perspective, Gower: Aldershot.

Boje, D. M. (1991), “The Storytelling Organization: A Study of Story Performance in an Office Supply Firm”, Administrative Science Quarterly, Vol. 36, No. 1, 106-126, March.

Boje, D. M. (1995), “Stories of the Storytelling Organization: A Postmodern Analysis of Disney as ‘Tamara-land”’, Academy of Management Journal, Vol. 38, No. 4, 997-1035, August.

Boje, D. M. (2002), Narrative Methods for Organizational and Communication Research, Sage, Thousand Oaks.

Boje, D. M., Luhman, J. T. and Baack, D. E. (1999), “Hegemonic Stories and Encounters Between Story Telling Organizations”, Journal of Management Inquiry, Vol. 8, No. 4, pp. 340-360, December.

Boje, D. M., Adler, T. R., and Black, J. A. (2005a), “Theatrical Facades and Agents in a Synthesized Analysis from Enron Theatre: Implications to Transaction Cost and Agency Theories”, Tamara Journal of Critical Postmodern Organization Science, Vol. 3, No. 2, pp. 39-56.

Boje, D.M., Driver, M. and Cai, Y. (2005b), “Fiction and Humor in Transforming McDonald’s Narrative Strategies”, Culture and Organization, Vol. 11, No. 3, pp. 195-208, September. 
Boudens, C. J. (2005), “The Story of Work: A Narrative Analysis of Workplace Emotion”, Organization Studies, Vol. 26, pp. 1285-1306.

Brown, J. S. and Duguid, P. (1991), “Organizational Learning and Communities of Practice: Toward a Unified View of Working, Learning, and Innovation”, Organizational Science, Vol. 2, No. 1, pp. 40-57.

Chamberlain, K., Stephens, C. and Lyons, A. C. (1997), “Encompassing Experience: Meanings and Methods in Health Psychology”, Psychology and Health, Vol. 12, pp. 691-709.

Chatterjee, S., Lubatkin, M., Scweiger, D., and Weber, Y. (1992) “Cultural Differences and Shareholder Value in Related Mergers: Linking Equity and Human Capital”, Strategic Management Journal, Vol. 13, pp. 319-334.

Collis, D., and Montgomery, C. (1998), “Creating Corporate Advantage”, Harvard Business Review, Vol. 76, No. 3, pp. 71-83.

Cyert, R.M. and March, J. G. (1963), A Behavioural Theory of the Firm, Prentice-Hall, Englewood Cliffs.

Czarniawska, B. (1998), A Narrative Approach to Organization Studies. Qualitative Research Methods Series 43, Sage Publications, London.

Dalton, M. (1959), Men Who Manage: Fusion of Feeling and Theory in Administration, Wiley, New York. 
Denzin, N. K. (1989), Interpretive Interactionism, Sage, London.

Fama, E.F. (1980), “Agency Problems and the Theory of the Firm”, Journal of Political Economy, Vol. 88, pp. 288-307.

Franzosi, R. (1998), “Narrative Analysis - Or Why (And How) Sociologists Should be Interested in Narrative”, Annual Review of Sociology, Vol. 24, pp. 517-554.

Gabriel, Y. (2000), Storytelling in Organizations. Facts, Fictions and Fantasies, Oxford University Press, Oxford.

Gabriel, Y. (Ed.), (2004a), Myths, Stories and Organizations. Pre-modern Narratives for Our Times, Oxford University Press, Oxford.

Gabriel, Y. (2004b), The Narrative Veil: Truth and Untruths in Storytelling, in Gabriel, Y. (Ed.), Myths, Stories and Organizations. Pre-modern Narratives for Our Times, Oxford University Press, Oxford, pp. 17-31.

Garfinkel, H. (1967), Studies in Ethnomethodology, Prentice Hall, Englewood Cliffs, NJ.

Georgakopoulou, A. (2006), “The Other Side of the Story: Towards a Narrative Analysis of Narratives-in-Interaction”, Discourse Studies, Vol. 8, No. 2, pp. 235-257.

Goffman, E. (1983), “The Interaction Order”, American Sociological Review, Vol. 48, pp. 117. 
Harrison, J.S., Hitt, M.A., Hoskisson, R.E., and Ireland, R.D. (1991), “Synergies and PostAcquisition Performance: Differences vs. Similarities in Resource Allocations, Journal of Management, Vol. 17, pp. 173-190.

Harris, L. (2005), “UK Public Sector Reform and the 'Performance Agenda’ in UK Local Government. HRM Challenges and Dilemmas”, Personnel Review, Vol. 34, No. 6, pp. 681696.

Haspeslagh, P. C. and Jemison, D. B. (1991), Managing acquisitions: Creating Value Through Corporate Renewal, The Free Press, New York, NY.

Hayward, M. and Hambrick, D. (1997), “Explaining the Premiums Paid for Large Acquisitions: Evidence of CEO Hubris”, Administrative Science Quarterly, Vol. 42, pp. 103127.

Jessop, T. S. and Penny, A. J. (1999), “A Story Behind a Story: Developing Strategies for Making Sense of Teacher Narratives”, International Journal of Social Research Methodology, Vol. 2, No. 3, pp. 213-230.

Kitching, J. (1967), “Why do Mergers Miscarry?”, Harvard Business Review, Vol. 45, No. 2, pp. 84-101.

Kotter, J.P. (1982), The General Managers, Free Press, New York, NY. 
Kotter, J. P., and Schlesinger, L.A. (1979), “Choosing Strategies for Change”, Harvard Business Review, Vol. 57, pp.106-114, March/April.

Kotter, J.P. and Cohen, D.S. (2002), The Heart of Change: Real Life Stories of How People Change Their Organizations, Harvard Business School Press, Cambridge, MA.

Labov, W. (1972), “The Transformation of Experience in Narrative Syntax”, In Labov, W (Ed.), Language in the Inner City: Studies in the Black English Vernacular, pp. 354-396. University of Philadelphia Press, Philadelphia.

Langellier, K.M. (1989), “Personal Narratives: Perspectives on Theory and Research”, Text and Performance Quarterly, Vol. 9, pp. 243-276.

Levinson, H. (1970), “A Psychologist Diagnoses Merger Failures”, Harvard Business Review, Vol. 48, No. 2, pp. 139-147.

Lewin, K. (1943), Forces behind food habits and methods of change. Bulletin of the National Research Council Vol. 108, pp. 35-65. Reprinted in Lewin, K. (2000), Resolving Social Conflicts and Field Theory in Social Science. American Psychological Association.

Lindblom, C. E. (1959), “The Science of Muddling Through”, Public Administration Review, Vol. 19, pp. 79-88.

Louis, A. M. (1982), “The Bottom Line of 10 Big Mergers”, Fortune, Vol. 3, pp. 84-89. 
Lubatkin. M. (1983), “Mergers and the performance of the acquiring firm”, Academy of Management Review, Vol. 8, No. 2, pp. 218-225.

March, J. G. and Simon, H. A. (1958), Organizations, Wiley, New York.

Mintzberg, H. (1973), The Nature of Managerial Work, Harper and Row, New York.

Mintzberg, H. (1978), “Patterns in Strategy Formation”, Management Science, Vol. 24, No. 9, pp. 934-948.

Mishler, E. G. (1986), Research Interviewing: Context and Narrative, Harvard University Press, Cambridge, MA.

Ochs, E. and Capps, L. (2001), Living Narrative, Harvard University Press, Cambridge, MA.

Orr, J. (1996), Talking About Machines: An Ethnography Of A Modern Job, Cornell, New York.

Parker, M. (2002), Against Management: Organisation in the Age of Managerialism, Polity, Cambridge.

Packard, D. (2006), The HP Way: How Bill Hewlett and I built Our Company, Harper Collins Publishing, New York.

Peters, T. and Waterman, R. (1982), In Search of Excellence, Harper and Row, New York. 
Pettigrew, A.M. (1985), The Awakening Giant, Blackwell, Oxford.

Polkinghorne, D. E. (1988), Narrative Knowing and the Human Sciences, State University of New York Press, Albany, NY.

Porac, J., Thomas, H. and Baden-Fuller, C. (1989), “Competitive Groups as Cognitive Communities: the Case of Scottish Knitwear Manufacturers”, Journal of Management Studies, Vol. 26, No. 4, pp. 397-416.

Ricoeur, P. (1984), (Trans.), McLaughlin, K. and Pellauer, D., Time and Narrative Volume 1, Chicago University Press, Chicago.

Shirley, R. C. (1977), “The Human Side of Merger Planning”, Long Range Planning, Vol. 10, pp. 35-39.

Stewart, R. (1967), Managers and their Jobs, Macmillan, London.

Stewart, R. (1976), Contrasts in Management: A Study of the Different Types of Manager’s Jobs: Their Demands and Choices, McGraw Hill, Maidenhead.

Stewart, R. (1982), Choices for the Manager. A Guide to Managerial Work and Behaviour, McGraw Hill, Maidenhead.

Thompson, P. and McHugh, D. (1995), Work Organizations, MacMillan, London. 
Tosi, H.L. and Gomez-Meijia, L.R. (1989), “The Decoupling of CEO Pay and Performance: an Agency Theory Perspective”, Administrative Science Quarterly, Vol. 34, pp. 169-190. Varaiya, N. (1987), “Determinants of premiums in acquisition transactions”, Managerial and Decision Economics Vol. 14, pp. 175-184.

Very, P., Lubatkin, M., Calori, P. and Veiga, J. (1997), “Relative Standing and the Performance of Recently Acquired European Firms”, Strategic Management Journal, Vol. 18, No. 8, pp. 593-614.

Vickers, D. A., (2005) A Study of Burnsland: Strategic Organisational Change and Power During an Acquisition. Doctoral Thesis, University of Lancaster.

Washbourne, N. and Dicke, W. (2001), “Dissolving Organization Theory? A Narrative Analysis of Water Management”, International Studies of Management and Organization, Vol. 31, No. 3, pp. 91-112, Fall.

Watson, T. and Petre, P. (2000), Father, Son \& Co.: My Life at IBM and Beyond. Bantam, New York.

Watson, T. J. (1994), In Search of Management. Culture, Chaos and Control in Managerial Work, International Thomson Business Press, London.

Whittington, R. (2000), What is Strategy and Does it Matter? Thomson Learning, London.

Willmott, A. and Wigdahl, N. (1997), “Making Mergers Work”, ICIS News, 15 September. 
Wright, P., Kroll, M. and Elenkov, D. (2002a), “Acquisition returns, increase in firm size, and chief executive officer compensation: the moderating role of monitoring”, Academy of Management Journal, Vol. 45, No. 3, pp. 599-608, June.

Wright, P., Kroll, M., Lado, A. and Ness, B.V. (2002b), “The structure of ownership and corporate acquisition strategies”, Strategic Management Journal, Vol. 23, pp. 41-53.

Author Contact Details:

David Vickers - University of Central Lancashire, Preston, PR1 2HE e-mail : davickers@uclan.ac.uk tel: $+44(0) 1772894641$. 